\title{
SUITABILITY OF OIL SHALE ASH AS A CONSTITUENT OF CEMENT
}

\author{
S. OYMAEL ${ }^{*}$
}

\author{
Mustafa Kemal University \\ Department of Civil Engineering \\ 31040 Antakya, Hatay, Turkey
}

\begin{abstract}
Physical and chemical characteristics of ashes formed at burning oil shale at temperatures 500, 600, 700, 800, 900 and $1030^{\circ} \mathrm{C}$ were studied. Standard procedures were used to determine both pozzolanic activity and binding parameters. The most suitable characteristics were provided with oil shale ash formed at $700{ }^{\circ} \mathrm{C}$. Ashes (15 and $\left.30 \%\right)$ were added to ordinary Portland cement. The optimum pozzolanic characteristics and performances were provided by the mixture containing $15 \%$ ashes. The mixes meet the corresponding Turkish standards, and therefore, this oil shale can be used as an admixture in Portland cement.
\end{abstract}

\section{Introduction}

Oil shale ash is formed at burning oil shale containing fossil energy. As shown by calculations, 40 billions $t$ oil shale provide $22 \cdot 10^{21}$ Joule energy. Consumption of large reservoirs of oil shale ash in the next three decades is ought to increase gradually, due to the fact that fossil energy resources of the Earth are diminishing [1]. Ash (spent shale) is formed at oil shale retorting as well. Oil shale ash (OSA)-added cements are produced in Germany, Estonia and China. A report given on the history of cement works includes also utilization of oil shale [2].

Considering pozzolanic activity of oil shale ash, various researches have been done on physical and chemical effects in cements containing oil shale ash in different ratios. The ash formed at retortig oil shale from central Jordan has been tested to evaluate its pozzolanic activity. According to the preliminary experiments, this ash had cementing properties [3]. Israeli oil shale, when burnt under certain conditions, yields ash which has also cementing properties [4]. Research on Estonian oil shale ash has shown that the use of burnt shale as a feedstock in production of cement is very

\footnotetext{
*Corresponding author: e-mail soymael@mku.edu.tr
} 


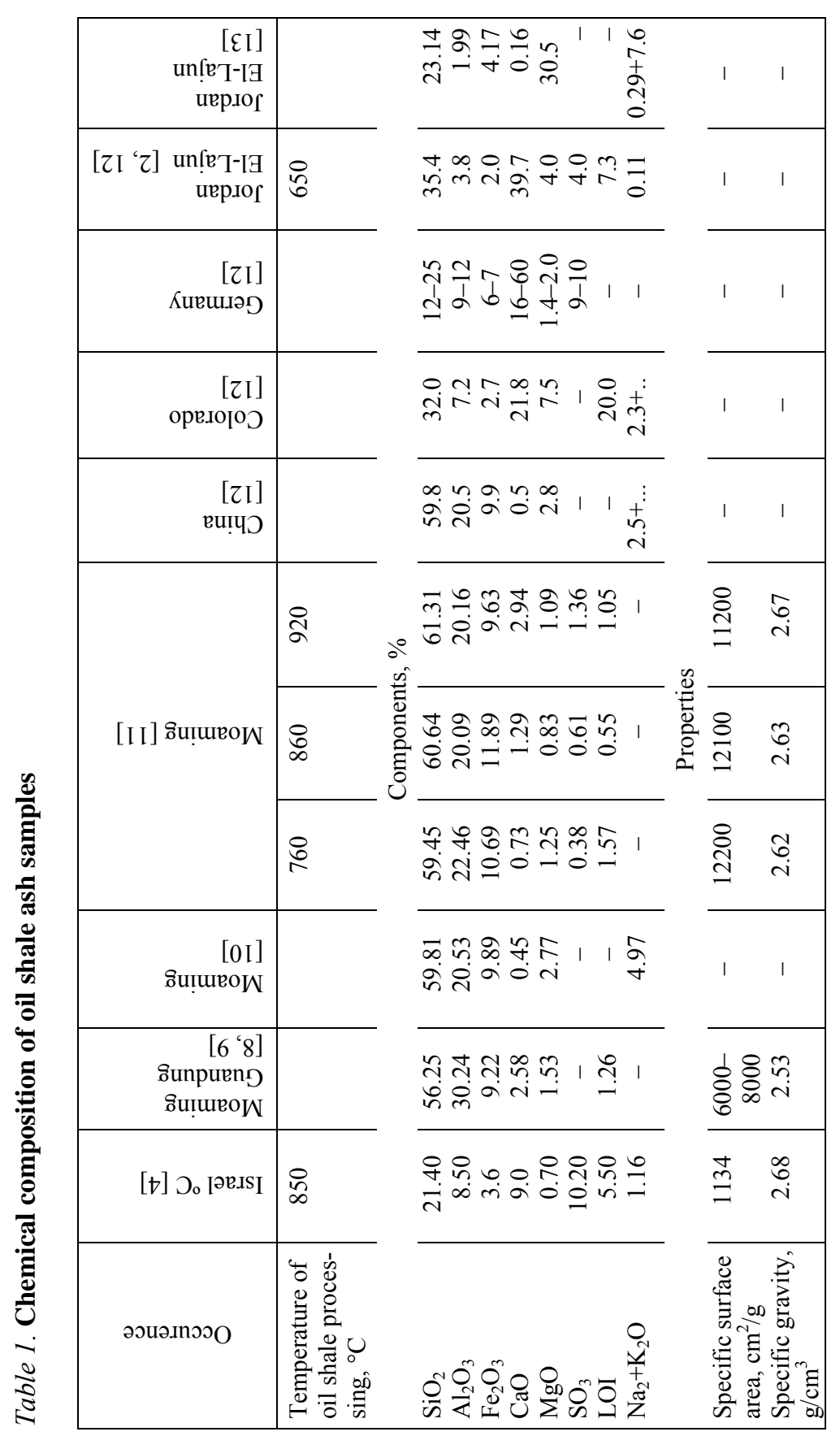


effective. Phase composition and binding properties of the finest fraction of burnt oil shale correspond to the specification DIN 1164, Part 100. By mixing 20 to $30 \%$ burnt oil shale with the clinker it is possible to produce a Portland oil-shale cement CEM II/B-T 52.5 which hardens quickly and has pozzolanic properties [5]. The properties and behaviour of oil shale ash have been determined and compared with the corresponding properties and behaviour of Portland cement by other researchers as well [3,6-8]. Composition and properties of ash pastes determined using the method of analysis for Portland cement pastes are given in Tables 1 and 2.

Table 2. Chemical composition of oil shale ash samples [4]

\begin{tabular}{|l|r|r|r|r|r|r|r|r|r|r|r|}
\hline Chemical & Oil & \multicolumn{5}{|c|}{${ }^{*} \mathrm{RK}$ ash formed at, ${ }^{\circ} \mathrm{C}$} & \multicolumn{3}{|c|}{${ }^{* *} \mathrm{FB}$ ash formed at, ${ }^{\circ} \mathrm{C}$} \\
\cline { 5 - 11 } & & & 600 & 700 & 800 & 900 & 1000 & 1100 & \multicolumn{2}{|c|}{650} & \multicolumn{2}{|c|}{760} \\
\cline { 5 - 11 } & & & & & & & Bed & Cyclone & Bed & Cyclone \\
\hline $\mathrm{SiO}_{2}$ & 13.8 & 17.6 & 20.8 & 21.9 & 21.6 & 22.9 & 23.0 & 13.6 & 12.5 & 15.5 & 15.0 \\
$\mathrm{Al}_{2} \mathrm{O}_{3}$ & 5.1 & 8.3 & 7.8 & 8.5 & 9.3 & 8.1 & 10.1 & 5.0 & 4.4 & 5.8 & 5.2 \\
$\mathrm{Fe}_{2} \mathrm{O}_{3}$ & - & - & - & - & - & - & 4.1 & 2.9 & 2.5 & 3.0 & 2.9 \\
$\mathrm{CaO}$ & 33.6 & 44.1 & 48.7 & 50.3 & 53.5 & 55.2 & 54.7 & 43.8 & 47.6 & 48.5 & 50.1 \\
$\mathrm{MgO}$ & 1.3 & - & - & - & - & - & 2.1 & 0.9 & 0.9 & 0.9 & 0.9 \\
$\mathrm{SO}_{3}$ & 5.6 & 4.0 & 5.0 & 7.7 & 4.3 & 2.1 & 0.1 & 7.5 & 8.3 & 7.6 & 8.3 \\
$\mathrm{LOI}$ & 36.8 & 18.0 & 7.0 & 3.0 & 0.6 & 1.0 & 1.2 & 21.5 & 18.8 & 13.5 & 13.1 \\
\hline
\end{tabular}

* RK: ash formed at combustion of crushed oil shale in a rotary kiln (2-3 kg batches).

**FB: ash formed at processing oil shale in a fluidized-bed unit.

Howewer, it was noted that the total porosity of the ash paste remained unchanged with time at ages exceeding three, possibly two, days. The properties of Portland cement and ash pastes of the same water/binder ratio were compared after previous extrapolation of data. It was concluded that, for the same water/binder ratio, the total porosity of the ash paste was greater than that of the cement paste, and the 28-day strength of the ash paste lower than the strength of its cement counterpart $[6,7]$.

The properties and behaviour of cement pastes of a high water/binder ratio have been studied and reported in details by Baum and Soroka [8]. Researches have been done on burning of oil shale ash, its hydration activity, strength, and chemical composition [6, 9, 11-15].

\section{Materials and methods}

\section{Cement}

Cement (CEM I) used in this study was provided by Elazig Cement Factory. Physical and chemical properties of cement are given in Table 3. 
Table 3. Chemical and physical properties of ordinary Portland cement (OPC)

(a) Chemical composition, $\%$

\begin{tabular}{|c|c|c|c|c|c|c|c|}
\hline $\mathrm{SiO}_{2}$ & $\mathrm{CaO}$ & $\mathrm{Al}_{2} \mathrm{O}_{3}$ & $\mathrm{Fe}_{2} \mathrm{O}_{3}$ & $\mathrm{MgO}$ & $\mathrm{SO}_{3}$ & LOI & $\begin{array}{c}\text { Le Chatelier } \\
\text { mm max. }\end{array}$ \\
\hline 19.78 & 63.0 & 5.60 & 3.35 & $\begin{array}{c}3.0 \\
\text { Limits }[17]\end{array}$ & 2.59 & 0.15 & 8 \\
$\begin{array}{l}\mathrm{CaO}+\mathrm{SiO}_{2}=50 \% \\
\mathrm{CaO} / \mathrm{SiO}_{2}=2\end{array}$ & & & & $<3.5$ & $<5$ & $\leq 10$ \\
\hline
\end{tabular}

(b) Physical properties

\begin{tabular}{|c|c|c|c|c|c|c|c|}
\hline \multirow{2}{*}{$\begin{array}{l}\text { Blaine } \\
\text { fineness, } \\
\mathrm{cm}^{2} / \mathrm{g}\end{array}$} & \multicolumn{2}{|c|}{$\begin{array}{c}\text { Setting time, } \\
\text { min }\end{array}$} & \multicolumn{2}{|c|}{ Compressive strength, $\mathrm{MPa}$} & \multirow{2}{*}{$\begin{array}{l}\text { Specific } \\
\text { gravity, } \\
\mathrm{g} / \mathrm{cm}^{3}\end{array}$} & \multicolumn{2}{|c|}{$\begin{array}{l}\text { Percentage } \\
\text { retained on }\end{array}$} \\
\hline & Min. & Max. & 7 days & 28 days & & $\begin{array}{c}200 \mu \mathrm{m} \\
\text { sieve }\end{array}$ & $\begin{array}{c}90 \mu \mathrm{m} \\
\text { sieve }\end{array}$ \\
\hline 3380 & 130 & 190 & 30.6 & 42.6 & 3.11 & 0.5 & 6.7 \\
\hline \multicolumn{8}{|c|}{ Limits [17] } \\
\hline 2800 & 75 & - & 16 & $\begin{array}{l}\geq 32.5 \\
\leq 52.5\end{array}$ & $3.10-3.15$ & - & - \\
\hline
\end{tabular}

\section{Oil shale ash}

Oil shale ash was obtained by burning oil shale at 500, 600, 700, 800, 900 and $1030{ }^{\circ} \mathrm{C}$ in the laboratory. Oil shale ash, by its nature, is a pozzolanic material. It contains not only much $\mathrm{Al}_{2} \mathrm{O}_{3}$, but also much of soluble $\mathrm{SiO}_{2}$ and $\mathrm{Al}_{2} \mathrm{O}_{3}$ [10], which would react with calcium hydroxide forming a precipitate.

\section{Method}

During this study, oil shale from the Ankara-Beypazari Cayirhan region of Turkey was burned at different temperatures between $500-1030{ }^{\circ} \mathrm{C}$. Physical and chemical properties of both oil shale ash and cement (that contained oil shale ash as an pozzolanic additive) were investigated in the laboratory conditions.

\section{Experimental}

\section{Physical and chemical properties of oil shale ash}

Changes in the physical and chemical structure of ash depending on combustion temperature are given in Tables 4 and 5. 
Table 4. Chemical composition and physical properties of ash from AnkaraCayirhan oil shale [14]

\begin{tabular}{|c|c|c|c|c|c|c|c|}
\hline \multirow{2}{*}{$\begin{array}{c}\text { Components }(\%) \text { and } \\
\text { properties }\end{array}$} & \multicolumn{6}{|c|}{ Combustion temperature, ${ }^{\circ} \mathrm{C}$} & \multirow{2}{*}{$\begin{array}{l}\text { Limits } \\
{[15]}\end{array}$} \\
\hline & 500 & 600 & 700 & 800 & 900 & 1030 & \\
\hline $\mathrm{SiO}_{2}$ & 29.26 & 28.6 & 39.12 & 28.4 & 20.25 & 14.54 & $\mathrm{~S}+\mathrm{A}+\mathrm{F} \geq 70 \%$ \\
\hline $\mathrm{Al}_{2} \mathrm{O}_{3}$ & 10.15 & 8.97 & 7.80 & 9.4 & 13.0 & 17.45 & \\
\hline $\mathrm{Fe}_{2} \mathrm{O}_{3}$ & 4.65 & 4.47 & 4.2 & 4.4 & 4.35 & 4.9 & \\
\hline $\mathrm{CaO}$ & 36.13 & 32.8 & 26.4 & 31.18 & 29.0 & 26.82 & \\
\hline $\mathrm{MgO}$ & 6.82 & 8.04 & 9.26 & 7.7 & 6.53 & 5.35 & $\leq 5 \%$ \\
\hline $\mathrm{SO}_{3}$ & 2.3 & 3.79 & 5.21 & 2.27 & 4.25 & 6.23 & $\leq 5 \%$ \\
\hline LOI & 3.24 & 6.47 & 3.82 & 8.82 & 15.4 & 19.84 & $\leq 10 \%$ \\
\hline Specific surface area, $\mathrm{cm}^{2} / \mathrm{g}$ & 6300 & 6200 & 6000 & 5900 & 5800 & 5700 & 3000 \\
\hline Specific gravity, $\mathrm{g} / \mathrm{cm}^{3}$ & 2.60 & 2.65 & 2.70 & 2.73 & 2.75 & 2.77 & - \\
\hline \begin{tabular}{l|l} 
Percent re- & $200 \mu \mathrm{m}$ sieve
\end{tabular} & 0.7 & 0.9 & 0.6 & 1.0 & 1.8 & 1.1 & $\leq 0.3$ \\
\hline tained on, $\% 90 \mu \mathrm{m}$ sieve & 5.85 & 4.0 & 4.0 & 9.0 & 9.8 & 4.7 & $\leq 8$ \\
\hline
\end{tabular}

Table 5. Activity of OSA [14]

\begin{tabular}{|c|c|c|c|c|c|c|c|c|c|}
\hline \multirow{2}{*}{\multicolumn{2}{|c|}{ Properties }} & \multirow[t]{2}{*}{ Days } & \multicolumn{6}{|c|}{ Combustion temperature, ${ }^{\circ} \mathrm{C}$} & \multirow{2}{*}{$\begin{array}{l}\text { Limits } \\
{[15]}\end{array}$} \\
\hline & & & 500 & 600 & 700 & 800 & 900 & 1030 & \\
\hline \multicolumn{2}{|c|}{$\begin{array}{l}\text { Compressive strength of } \\
\text { OSA-paste, } \mathrm{MPa}\end{array}$} & 28 & - & - & 10 & - & - & - & \\
\hline $\begin{array}{l}\text { Lime } \\
\text { activity } \\
\text { method }\end{array}$ & $\begin{array}{l}\text { Compressive } \\
\text { strength, } \\
\text { MPa }\end{array}$ & 7 & 5.5 & 9.1 & 13 & 10.1 & 8.7 & 4.2 & 4.0 \\
\hline
\end{tabular}

\section{Investigation of ash paste}

For measuring the strength of the pastes $40 \times 40 \times 160 \mathrm{~mm}$ samples of ashes produced at different temperatures were prepared. Water/ash (W/A) ratio was 0.40 , compressive and tensile strength were measured after 7 and 28 days. Samples, curing in water, were inverted on the 15 th day. The pastes made from the ash formed at $700{ }^{\circ} \mathrm{C}$ were strenghest (Fig. 1). Pastes produced from ashes obtained at 500 and $1030^{\circ} \mathrm{C}$ were dispersed when handled.

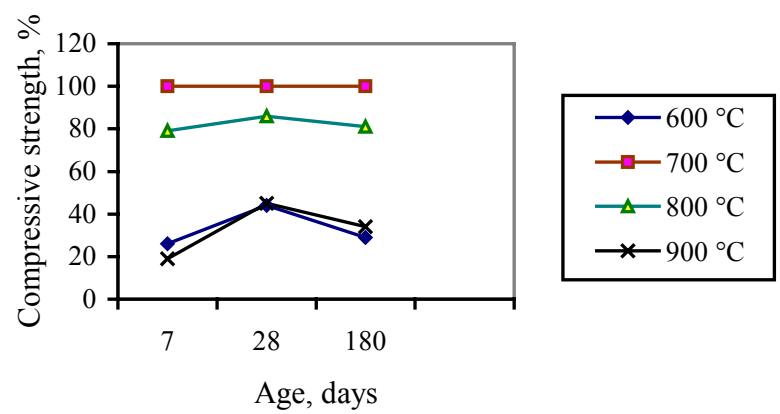

Fig. 1. Strength of ash pastes (100\% OSA) 


\section{Investigation of cements with ash addition}

The ash obtained at $700{ }^{\circ} \mathrm{C}$ was observed to have optimum values in terms of fineness, activity and strength. Therefore, this ash was used to investigate the effect of $30 \%$ ash additive in cement [18].

Water content of the paste was changed by addition of oil shale ash (15 or $30 \%$ ) into cement (three replicates). The paste used in experiments must be of standard consistency. The fineness of ash was similar to that of cement. Water content of cement rises depending on the rate of added ash as shown in Table 6.

Physical, and chemical properties of the samples of ordinary Portland cement and cement with $15 \%$ and $30 \%$ ash additives are given in Table 7 . The compatibility of the obtained values were checked against TS EN 197-1 standard values. TS EN 197-1 is valid only in cases when the percentage of pozzolanic additive is about 15 [19]. Figure 2 shows compressive strength of cements with OSA additives after 28 days of hardening.

Table 6. Change in water content of cement containing OSA

\begin{tabular}{|c|c|c|}
\hline OPC & OSA, $\%$ & Water, $\%$ \\
\hline 100 & 0 & 23 \\
85 & 15 & 25 \\
70 & 30 & 20 \\
\hline
\end{tabular}

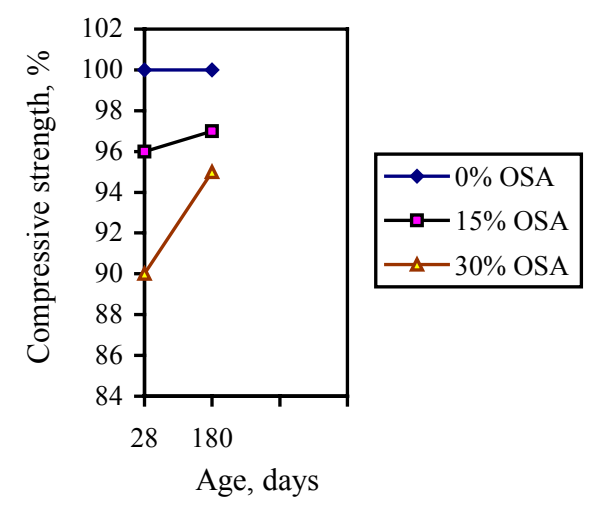

Fig. 2. Changes in compressive strength of pastes after their hardening in water for 28 days 
Table 7. Composition and properties of OPC, OSA and OPC with OSA additives

\begin{tabular}{|c|c|c|c|c|c|}
\hline \multicolumn{2}{|c|}{$\begin{array}{l}\text { Components }(\%) \text { and } \\
\text { characteristics }\end{array}$} & $\begin{array}{c}\text { OSA } \\
\text { (Oil shale ash) }\end{array}$ & $\begin{array}{c}0 \% \text { OSA } \\
\text { Substituted } \\
\text { cement } \\
(\text { OPC 32.5) }\end{array}$ & $\begin{array}{c}15 \% \text { OSA } \\
\text { Substituted } \\
\text { cement }\end{array}$ & $\begin{array}{c}30 \% \text { OSA } \\
\text { Substituted } \\
\text { cement }\end{array}$ \\
\hline \multicolumn{2}{|l|}{$\mathrm{CaO}$} & 26.40 & 63.0 & 56.16 & 50.12 \\
\hline \multicolumn{2}{|l|}{$\mathrm{SiO}_{2}$} & Limits [17] & 19.78 & 16.79 & 15.45 \\
\hline \multicolumn{2}{|l|}{$\mathrm{Al}_{2} \mathrm{O}_{3}$} & \begin{tabular}{l|l}
7.80 & $\mathrm{~S}+\mathrm{A}+\mathrm{F} \geq 70 \%$
\end{tabular} & 5.60 & 5.44 & 4.9 \\
\hline \multicolumn{2}{|l|}{$\mathrm{Fe}_{2} \mathrm{O}_{3}$} & 4.20 & 3.35 & 3.05 & 3.53 \\
\hline \multicolumn{2}{|l|}{$\mathrm{MgO}$} & $9.26(\mathrm{Lim} . \leq 5 \%)[17]$ & 3.0 & 4.87 & 5.37 \\
\hline \multicolumn{2}{|l|}{$\mathrm{SO}_{3}$} & $5.21(\mathrm{Lim} . \leq 5 \%)[17]$ & 2.59 & 3.04 & 3.39 \\
\hline \multicolumn{2}{|l|}{$\mathrm{Na}_{2} \mathrm{O}+\mathrm{K}_{2} \mathrm{O}$} & - & 0.15 & - & - \\
\hline \multicolumn{2}{|l|}{ Loss of ignition } & $3.82(\mathrm{Lim} . \leq 10 \%)[17]$ & 1.73 & 4.36 & 6.2 \\
\hline & - & $\leq 0.1$ & - & - \\
\hline \multirow{2}{*}{\multicolumn{2}{|c|}{$\begin{array}{l}\text { Blaine surface area, } \mathrm{cm}^{2} / \mathrm{g} \\
\text { Specific gravity, } \mathrm{g} / \mathrm{cm}^{3}\end{array}$}} & 6000 (Lim. 3000) [17] & 3180 & 3400 & 3450 \\
\hline & & 2.7 & 3.15 & 3.12 & 3.11 \\
\hline \multirow{4}{*}{$\begin{array}{l}\text { Compression } \\
\text { strength (Lime } \\
\text { activity [19]), } \\
\mathrm{N} / \mathrm{mm}^{2}\end{array}$} & Days & & & & \\
\hline & 2 & 15.3 & - & - & - \\
\hline & 7 & $23.9(13.0)$ & - & - & - \\
\hline & 28 & $29.5(8.1)$ & - & - & - \\
\hline \multirow{4}{*}{$\begin{array}{l}\text { Compression } \\
\text { strength } \\
\text { (Flexural } \\
\text { strength [19]), } \\
\mathrm{N} / \mathrm{mm}^{2} \\
\text { Percent retained } \\
\text { on, \% }\end{array}$} & 7 & - & $30.6(5.7)$ & $30.9(5.9)$ & $24.5(4.5)$ \\
\hline & 28 & $10(1.8)$ & $42.6(6.8)$ & $44.4(7.0)$ & $37.8(6.5)$ \\
\hline & $\begin{array}{l}200 \mu \mathrm{m} \\
\text { sieve }\end{array}$ & - & - & - & - \\
\hline & $\begin{array}{l}90 \mu \mathrm{m} \\
\text { sieve }\end{array}$ & - & - & - & - \\
\hline
\end{tabular}

\section{Hydration temperature}

This experiment was conducted at Turkish Cement Manufacturers Association Laboratories. Hydration temperature determines the relationship between addition rates and combustion temperature of oil shale and also intensity and direction of this relationship. Hydration heat gives an idea about beginning and ending of the setting period, hardening period of cement and the field of application. In general, it is difficult to measure hydration temperature and to consider it an indication of exothermic reaction between cement and water. Hydration is observed, and its degree is either a value reached at the end of a long hydration period, or it is calculated. The main objective of the experiment was to determine the difference between dissolution heat of dry cement and that of hydrated cement. Both cement and hydrated cement paste samples were tested by using $4.180 \pm 0.05 \mathrm{~g}$ samples, prepared by weight in accordance with the corresponding standards. During the experiment, the increase in temperature and heating loss were 
determined. The values of hydration heat were measured in different specific solutions and calculation methods are given in Table 8 and Fig. 3.

\section{Table 8. Hydration of OSA-added cements}

\begin{tabular}{|l|c|c|}
\hline \multirow{2}{*}{$\begin{array}{c}\text { Specimen } \\
\text { (Mixture) }\end{array}$} & Hydration temperature, cal $/ \mathrm{g}(\times 4.1868 \mathrm{~J} / \mathrm{g})$ \\
\cline { 2 - 3 } & 7 days & 28 days \\
\hline OSA 0\% control & 63.81 & 72.98 \\
15\% OSA & 60.66 & 70.51 \\
$30 \%$ OSA & 58.46 & 69.10 \\
\hline
\end{tabular}

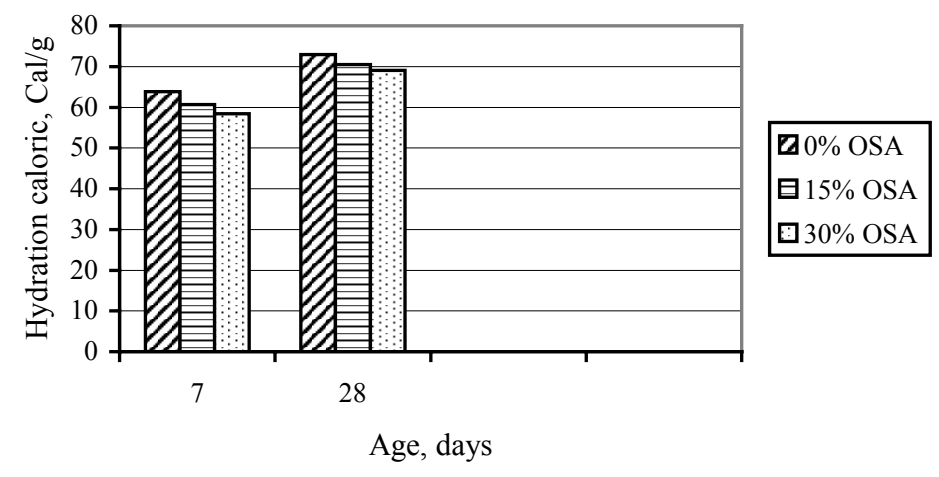

Fig. 3. Hydration of OSA-added cements

\section{Investigation of internal structure}

Comparison of X-ray diagrams of OPC and OSA $\left(700{ }^{\circ} \mathrm{C}\right.$ and $\left.900{ }^{\circ} \mathrm{C}\right)$ shows that the ash obtained at $700{ }^{\circ} \mathrm{C}$ contains more C-S-H in both 1- and 28-day samples. This finding is considered to be reasonable (Figures 4 and 5). 

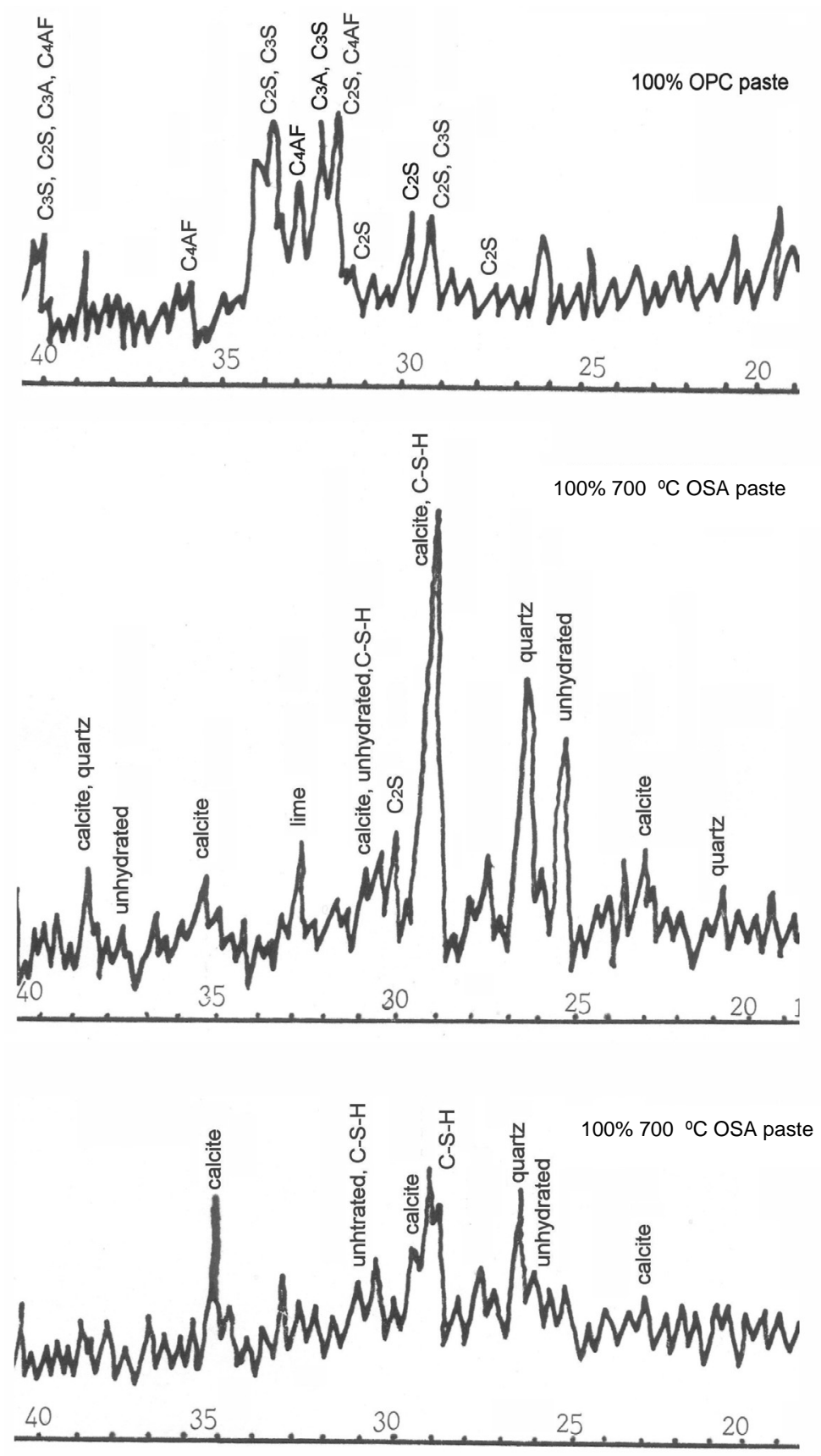

${ }^{\circ} 2 \theta$

Fig. 4. XRD analysis of cement and OSA pastes after the $1^{\text {st }}$ day of hardening 
$100 \%$ OPC paste
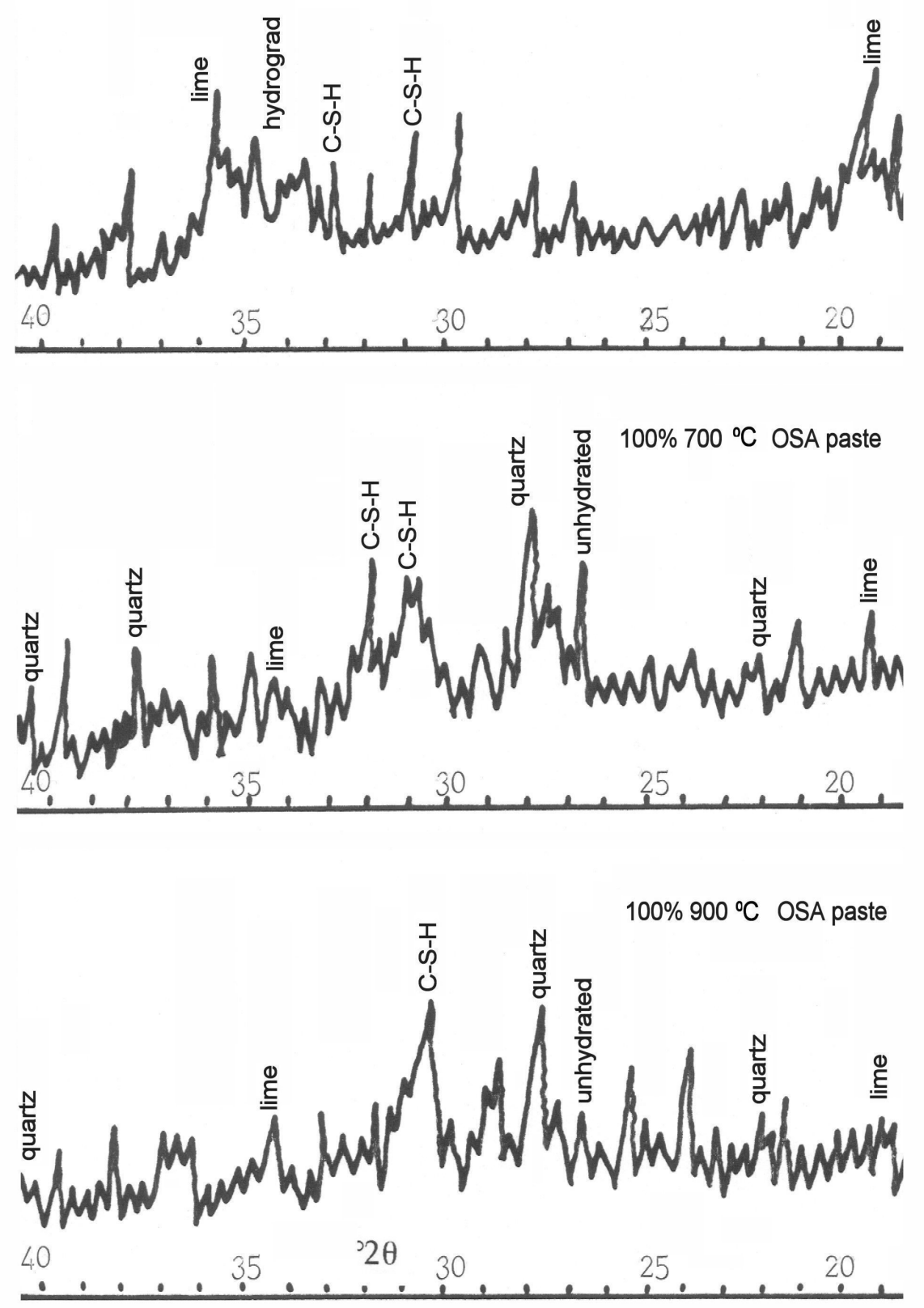

Fig. 5. XRD analysis of cement and OSA pastes after the $28^{\text {th }}$ day of hardening 


\section{Results and discussion}

Physical and chemical characteristics of ashes obtained from oil shale of the Ankara-Beypazari Cayirhan region do not match with the data obtained in previous studies. The oil shale ashes studied in previous works $[3,6]$ were obtained at burning oil shale at 650 and $850^{\circ} \mathrm{C}$. Physical and chemical characteristics of OPC samples examined in previous works differ from OPC characteristics in the present study. Since geological conditions of oil shale may differ accross countries and regions, the optimum values of chemical and physical characteristics measured for ashes obtained at burning oil shales from different regions at $700{ }^{\circ} \mathrm{C}$ are not the same. Therefore, appropriate mixtures should be determined by considering chemical and physical characteristics of each different ash and cement.

Chemical and physical characteristics of ashes obtained at burning oil shales from different locations at different temperatures (e.g. 500, 600, 700, $800,900,1030(1000){ }^{\circ} \mathrm{C}$ given in literature differ from the results of the current study (Tables 1, 2 and 4).

As for the composition, the ashes obtained in this study were found to be similar with high-lime fly ashes. When the values in Table 4 are compared with the limits of TS 25 [17], one can see that the amount of $\mathrm{SO}_{3}$ at $700{ }^{\circ} \mathrm{C}$ is somewhat higher than the allowed amount, and the amount of $\mathrm{MgO}$ is slightly greater than the limit defined in TS 25 . On the other hand, the total percentages of $\mathrm{SiO}_{2}, \mathrm{Al}_{2} \mathrm{O}_{3}$ and $\mathrm{Fe}_{2} \mathrm{O}_{3}$ meet the suggested $70 \%$ limit for high-lime fly ashes.

Pozzolanic activity of ash is adequate. The $13 \mathrm{MPa}$ pressure measured is much greater than the limit value $4 \mathrm{MPa}$ (Table 5). Because of a relatively high lime content, binding properties of ash are naturally of a low value. Such a low binding property is caused also by large amount of $\mathrm{SO}_{3}$.

Chemical analysis of cements with OSA additive showed that the $\mathrm{MgO}$ limit was provided with $15 \%$ ash addition. The $3.5 \%$ limit value of $\mathrm{SO}_{3}$ was obtained in both cases (15\% and 30\% additions). Silica and aluminum module are in the range of normal values, and lime module in cement with $30 \%$ additive is low [16]. The conclusion can be made that high lime module indicates cement containing free lime and getting stale early. Neither at the $15 \%$ - nor $30 \%$-addition, heating loss did not exceed the limit of $4 \%$ at $700{ }^{\circ} \mathrm{C}$ (Table 7).

Considering the data in Table 7, it was observed that all chemical characteristics of the sample containing $15 \%$ OSA met the standard limit values. Full compatibility of the $\mathrm{Al}_{2} \mathrm{O}_{3}$ value of this cement with that of the OPC sample and lower amount of $\mathrm{MgO}$ and $\mathrm{SO}_{3}$ indicate that it contains no undesirable substances such as ettringite, monosulfate aluminate and the volume would not expand. Therefore, the Le Chatelier experiment was made to study expansion, and it was below the standard value of $10 \mathrm{~mm}$. The amount of $\mathrm{CaO}$ in cement with $30 \%$ additive decreased dramatically. This situation is not acceptable since it causes some negative effects in formation 
of calcium-silicate-hydrate (C-S-H). The result of the Le Chatelier experiment with the $30-\%$ sample was less than that in the case of the $15-\%$ one.

Since specific mass of ash is small, it lowers specific mass of cement. However, the final specific mass of cements containing additive is in the normal range. Regular consistency of cements containing OSA is more viscose due to somewhat higher amount of water. This situation is related to rough and pore composition of ash particles and their blaine fineness.

Hydration heat of cement with ash addition is less than expected. It proves that this cement can be used in hot climate and massive concrete blocks.

As for chemical and physical characteristics of cements containing additive, the 28 -day strength of cement with $15 \%$ additive is higher than that of cement with $30 \%$ additive. This indicates its pozzolanic suitability. It also can be explained by reduction of $\mathrm{Ca}(\mathrm{OH})_{2}$ content as indicated by peaks in $\mathrm{X}$-ray diagrams of ash (Figures 4 and 5). However, both activity of ash and the experiments with 28 days old samples elucidate the expected reduction in $\mathrm{Ca}(\mathrm{OH})_{2}$ and development of C-S-H in cement samples containing OSA.

C-S-H in the $700{ }^{\circ} \mathrm{C}$ sample was more developed than that in OPC and in the $900{ }^{\circ} \mathrm{C}$ sample, as demonstrated by their X-ray spectra (Figures 4 and 5). It is so because of quick consumption of portlandite by OSA and $\mathrm{C}_{3} \mathrm{~S}$ consumption because of acceleration of $\mathrm{C}_{3} \mathrm{~S}$ hydration by $700{ }^{\circ} \mathrm{C}$ OSA. $700{ }^{\circ} \mathrm{C}$ samples contain less $\mathrm{Ca}(\mathrm{OH})_{2}$ than $\mathrm{OPC}$ because active silica $\left(\mathrm{SiO}_{2}\right)$ in OSA reacts quickly with $\mathrm{Ca}(\mathrm{OH})_{2}$ producing $\mathrm{C}-\mathrm{S}-\mathrm{H}$ and reducing $\mathrm{Ca}(\mathrm{OH})_{2}$ amount. This preferable situation was confirmed by XRD spectra of $900{ }^{\circ} \mathrm{C}(100 \%)$ OSA samples hardened for 28 days (Figures 4 and 5). Examination of the 1-day OSA samples, obtained by burning at $900{ }^{\circ} \mathrm{C}$, showed that portlandite was disappeared at disintegrating (it means joined with quartz), and the formation of C-S-H was not complete.

\section{Conclusions}

The additives for cements obtained at $700{ }^{\circ} \mathrm{C}$ by burning oil shale of the Ankara-Beypazari Cayirhan region in Turkey and added to cement at the ratio of $15 \%$ by its weight meet the standards for cement additives and agree with previous studies on the subject.

\section{Acknowledgement}

The author would like to thank Prof. Asım Yeginobali, retired faculty member of Middle East Technical University (METU) and current Research and Development Director of the Turkish Cement Manufacturers' Association. 


\section{REFERENCES}

1. Mine Survey Search General Directorate, oil shale ashes and Turkish oil shale reserves, service special report number: 9202, Petroleum and Geothermal Energy Department Chairmanship, 1989 [in Turkish].

2. Feige, F. Zur wirtschaftlichen Verwendung des Ölschiefers bei Rohrbach Zement // Zement-Kalk-Gips (Cement-Lime-Gypsum). 1992. Vol. 45, No. 2. P. 53-62.

3. Smadi, M. M., Haddad, R. H. The use of oil ash in Portland cement concrete // Cem. Concr. Compos. 2003. Vol. 25, No. 1. P. 43-50.

4. Ish-Shalom, M., Bentur, A., Grinberg, T. Cementing properties of oil-shale ash: I. Effect of burning method and temperature // Cem. Conr. Res. 1980. Vol. 10, No. 6. P. 799-807.

5. Kikas $W$. Composition and binder properties of Estonian kukersite oil-shale ash // ZKG International. 1997. Vol.50, No. 2. P. 112-126.

6. Baum, H., Soroka, I., Bentur, A. Properties and structure of oil shale ash pastes I: Composition and physical features // Cem. Concr. Res. 1985. Vol. 15, No. 2. P. 303-314.

7. Baum, H., Soroka, I., Bentur, A. Properties and structure of oil-shale ash pastes I: Comparison and physical features // Cem. Concr. Res. 1985. Vol. 15, No. 2. P. 303-314.

8. Baum, H., Soroka, I. Comparison between oil shale ash and cement pastes // Cem. Concr. Res. 1986. Vol. 16, No. 1. P. 40-46.

9. Paglia, C. S. B., Wombacher F. J., Böhni, H. K. Hydration, strength, and microstructural development of high early-strength $\mathrm{C}_{4} \mathrm{~A}_{3} \mathrm{~S}$ activated burnt oil shalebased cement system// ACI Materials Journals, September-October 2001. P. 379-385.

10. Chan, $S$. Y. N., Ji, X. Water sorptivity and chloride diffusivity of oil shale ash concrete // Constr. Build. Mater. 1998. Vol. 12, No. 4. P. 177-183.

11. Feng, N. Q., Chan, S. Y. N., He, Z.S., Tsang, M. K. C. Shale ash concrete// Cem. Concr. Res. 1997. Vol. 27, No. 2. P. 279-291.

12. Guvanshu, T., Xingshan, Z., Zhongpu, H., Zihuhua, X. Multipurpose use of shale ash and its paragenetic mineral in China. International conference an oil shale and shale oil in Canjunetton With, Colorade Shcool of Mines oil Shale Symposium, Bejing-China, May 1988.

13. Zhangpu, H., Qihai, X. Properties of shale ash (Taken from the boiling furnace) Portland cement. International conference an oil shale and shale oil in Canjunetton With, Colorade School of Mines oil Shale Symposium, BejingChina, May 1988.

14. Smadi, M., Yeginobali, A., Khedaywi, T. Potential uses Jordanian spent oil shale ash as a cementive material // Magazine of Concrete Research. 1989. Vol. 41, No. 148. P. 183-190.

15. Nazzal, J. M. Jordan oil shale and recommended de sign of I. C. Engine using solid fuels. B.Sc. of Mech. Eng. Project Yarmouk University, 1987.

16. Oymael, $S$. The suitability of oil shale ash as an admixture in cement and concrete. PhD dissertation, Firat University, Elazig: 1995. p. 163 [in Turkish].

17. Turkish Standards Institute. TS 25-1975, Trass, Ankara, Turkey [in Turkish1]. 
18. Yeğinoball $A$. Effectiveness of oil shale ash in recuding alkali-silica reaction expansions // Material and Structures. 1993. Vol. 26, No. 3. P. 159-166.

19. Turkish Standard Institute. TS 197-1, 2002, Cement, Ankara, Turkey [in Turkish].

Presented by M. V. Kök

Received May 16, 2005 